\title{
Status Quo and Proposals in the Selection of Teaching Materials for Foreign Language Majors at Chinese Universities-An Integrated Course in Elementary Japanese as an Example*
}

\author{
Peng Yuquan \\ Southwest University, Chongqing, China
}

\begin{abstract}
With the considerable amount of textbooks and teaching materials published in China, both administrators and teachers are still puzzled when they are selecting proper materials for the students majoring in foreign languages. Selection of teaching materials will have a direct impact on both program building and outcome of the graduates in the program. This paper attempts to discuss the current situation of teaching material selection for foreign language majors, analyze the factors in material selection, and put forward some proposals of how to select proper teaching materials for foreign language majors.
\end{abstract}

Keywords: teaching materials, foreign language majors, status quo, proposals

\section{Introduction}

Teaching materials serve as the most important resources of education and the fundamental guidance of classroom teaching. With the huge amount of textbooks and teaching materials published in China, administrators and teachers in many departments of Chinese universities are still puzzled about how to select appropriate materials. Therefore, the author, based on his own teaching experience, conducted a case study of the teaching materials for the Integrated Course in Elementary Japanese to explore the status quo of material selection in Chinese universities followed by a factor analysis and proposals of material selection.

\section{Status Quo of Teaching Material Selection in Chinese Universities}

In recent years, textbooks with typical features have been published, among which the good and bad intermingled, which causes a good many problems for administrators and teachers. For example, in the past 10 years, with the increasing number of Japanese learners and Japanese departments established at Chinese universities, the Japanese language has become "a major foreign language, second only to English" (Xiu, 2014). Several years ago, complaints of a lack of appropriate textbooks were often heard among Japanese educators, but now, a large number of teaching materials have been published by all major publishers with diversified types and designs. Taking just the textbook for the Integrated Course in Elementary Japanese (or Intensive

\footnotetext{
* This paper is part of the educational research project "Research of Innovative Mode of Teaching at the Elementary Stage of Minor Language Education" (Project No. 2013JY096) of Southwest University.

Peng Yuquan, Ph.D., associate professor, College of International Studies, Southwest University.
} 
Reading) as an example, the author has found at least 10 (see Table 1). Against this background, selection of textbooks becomes a major issue.

Table 1

Recent Textbooks for the Course of Elementary Integrated Japanese

\begin{tabular}{|c|c|c|c|}
\hline Name of textbook & Editor (or chief editor) & Publisher & Year \\
\hline New Essential Japanese (Revised) & $\begin{array}{l}\text { Jian Peizhi, Sun Zongguang, Xu } \\
\text { Huachang, Zhao Minhua, and Wei Qu }\end{array}$ & Shanghai Translation Publishing House & 2005 \\
\hline Japanese Intensive Reading & Su Jiugao and Zhou Fuyi & $\begin{array}{l}\text { Foreign Language Teaching and Research } \\
\text { Press }\end{array}$ & 2006 \\
\hline Japanese & Liu Dalan and Wang Xin & Wuhan University Press & 2007 \\
\hline Modern Japanese Course & $\mathrm{Xu} \mathrm{Shu}$ & East China Normal University Press & 2010 \\
\hline Basic Integrated Japanese Course & Lin Hong and Cao Dafeng & Higher Education Press & 2010 \\
\hline New Japanese (Revised) & Zhou Ping and Chen Xiaofen & $\begin{array}{l}\begin{array}{l}\text { Shanghai Foreign Language Education } \\
\text { Press }\end{array} \\
\end{array}$ & 2009 \\
\hline Comprehensive Japanese (Revised) & Peng Guanglu and Michiyo Moriya & Peking University Press & 2010 \\
\hline Foundational Japanese Course & Li Hua and Cui Wanyou & Dalian University of Technology Press & 2010 \\
\hline Integrated Japanese Course & $\begin{array}{l}\text { Chen Xiaofen, Lu Jinghua, Ji Lingen, } \\
\text { etc. }\end{array}$ & $\begin{array}{l}\begin{array}{l}\text { Shanghai Foreign Language Education } \\
\text { Press }\end{array} \\
\end{array}$ & 2011 \\
\hline Japanese Course (3rd ed.) & Xu Xiaoming (Producer) and Reika & $\begin{array}{l}\begin{array}{l}\text { East China University of Science and } \\
\text { Technology Press }\end{array} \\
\end{array}$ & 2012 \\
\hline Japanese Intensive Reading & Yang Shuceng & $\begin{array}{l}\text { University of International Business and } \\
\text { Ecnomics Press }\end{array}$ & 2013 \\
\hline
\end{tabular}

Based on the survey and interview of some administrators of Japanese departments, the author found the following problems in textbook selection.

\section{Weak Awareness of Teacher Participation in Textbook Selection}

Teaching materials are the most important teaching resources, which exert influence on both the quality of teaching and talent cultivation. Against the background of the latest requirement for Japanese talents in the new century, the importance of textbooks in Japanese education is even more prominent. The new ideas of classroom teaching emphasize teachers' active participation in curriculum development, such as starting an open teaching beyond the limit of the textbooks and expanding the space of teaching in the way of "using the textbooks" rather than "teaching the textbooks". However, in Chinese universities, Japanese teachers are disadvantaged in terms of professional qualifications. In this sense, there are some difficulties in encouraging the Japanese teachers to participate in the selection of textbooks. At the same time, there is also a lack of textbook selection concept among most Japanese teachers, still less of textbook editing and development.

\section{Administrative Dominance in Textbook Selection}

At present, Chinese education is still administration dominated. The teachers of all courses do not have much say on what textbooks to use in their teaching. This has caused many problems in teaching. The specific rules and regulations concerning textbook selection in most universities are nothing better than written words, which offer teachers no real choice in textbook selection. The administrators, the real selectors of textbooks, often decide a textbook according to the introduction or publicity made by the publishers or whether they provide any teacher training, especially textbooks for public courses ( $\mathrm{Gu} \& \mathrm{Lu}, 2009)$. The limitations of such administrative dominance in textbook selection are obvious. Although some of the administrators had the experience of being teachers and some knowledge of language teaching, they are still limited in their understanding of specific things about teaching. The content of textbooks in foreign language education is very 
extensive, which requires professional knowledge in its selection. Therefore, innovation is expected of the administrative dominance in the context of China's educational curriculum reform.

\section{Irrelevance of Objectives and Content to the Syllabus}

Among the actually used Japanese textbooks, some are edited by Japanese experts, some by famous publishers, some as comprehensive textbooks, some as elementary textbooks, and some published in Japan for overseas students. It could be said that different textbooks are selected for different reasons. The National Syllabus for the Elementary Stage of Japanese Majors for Japanese beginners specifies that:

The syllabus is targeted at the first- and second- year Japanese major beginners. The objectives are to guide students' learning; to train their listening, speaking, reading, and writing; to improve their comprehensive language skills; to offer them knowledge of Japanese society and culture; to deepen their understanding of different cultures; and to lay a foundation for future study. The content for the elementary stage includes Japanese pronunciation, characters, words, grammar, sentence patterns, and ideational functions. (Japanese Language Teaching Advisory Board, 2001, pp. 1-2)

It could be said that the syllabus defines directions for textbook selection. However, many universities did not follow the directions in the selection of their textbooks.

\section{Lack of Openness and Transparency in the Procedure of Textbook Selection}

In the first decade of the 21 st century, after the curriculum reform in the compulsory education, a number of teaching material selection committees were established in various regions. They comprise of members from educational administrative departments, research sectors, scholars, school principals, teachers, and parents following a certain ratio. A quarter of them are administrators, and three quarters are scholars, teachers, and parents. A three-step procedure is adopted in textbook selection. For the first step, textbooks are introduced for first impression and tentative views. For the second step, a meeting is held for a vote. The third step is to come to a final decision at the closed meeting. The selection is followed by textbook training given by the publishers and teacher training by the educational departments to ensure the best use of the chosen textbooks in classroom teaching (Yu, 2003). By contrast, textbook selection in higher education is more flexible. According to Lu (2010), "Although not as that important as in secondary education, teaching materials in the higher education still play a crucial role in teaching, especially in elementary courses for freshmen and sophomores". However, many colleges and universities in China have not established their own teaching material selection systems till now. The administrators have the major say of the textbooks, while the teachers and students are not involved. In this sense, the problem of lack of openness and transparency in the selection procedure was identified.

\section{Factors in Teaching Material Selection}

A number of factors are involved in the selection of teaching materials for the Integrated Course in Elementary Japanese.

\section{Obscurity in the Orientation and Objective Setting of the Japanese Major}

In some universities, the definition of the Japanese major tends to be too general, or rather abstract, without consideration of the specific factors, such as teachers, students, and other teaching resources. Many universities hastily borrow models or definitions from other higher level universities rather than making their own according to national, social, or especially local economic development. The objective of talent training is often far from feasible and beyond the real situation or its own capability. In this context, the curriculum also borrows or follows other universities, which result in inappropriate course setting and the gap between teaching 
and objectives of talent training. What is even worse, to meet the requirement of administrative departments, some universities take the curriculum for the Japanese majors from another university and use the same textbook for students from sharply different backgrounds. When problems arise, teachers at these universities would question the quality of the textbooks and would feel even more confused when they decide to find a different set of textbooks.

\section{Insufficiency of the Japanese Textbooks to Meet the Diversified Demand of Japanese Graduates}

Back to the 1980s and the 1990s, as the reform and opening-up deepened and Japanese business, trade, and economic exchange bloomed, the demand for Japanese talents was increasing. However, that demand was type restricted, including mainly the need of Japanese translators, tour guides, etc.. There were only relatively small types and versions of textbooks for Japanese majors, thus, offering only a small number of choices. In the 21 st century, with social and economic development, the demand for talents is more diversified. The Japanese graduates are expected not only to have a good mastery of Japanese language skills, such as listening, speaking, reading, writing, and translating, but also to have good cross-cultural communicative competence and specific knowledge in the fields of business, foreign trade, foreign affairs, translation, marketing, etc.. To train such versatile talents, universities have to find relevant textbooks for the Japanese education. However, the fact is that such textbooks are nowhere to be found, which has left the educational institutions in an embarrassing situation.

\section{Insufficient Emphasis on Textbooks in the Construction of the Japanese Major}

In building up the Japanese major, much more importance is given to teacher resources, for example, encouraging teachers to gain degrees and do academic research, with less emphasis on their teaching or use of textbooks. As a result, many teachers select textbooks according to personal favourites or the decision of the deans or directors. Although programs are specified in many Japanese departments, no explanation or elaboration is made to all the teachers, which caused confusion among average teachers in terms of the orientation, objectives, and courses of the Japanese major, not to mention the relation between different types of courses. Therefore, the textbooks are selected without the consideration of their relevance to training objectives. All textbooks or other materials are randomly selected to be used in teaching as long as they are nationally planned ones or published by famous presses.

\section{Rigid Use of Textbooks as a Mere Instrument of Teaching}

Rigid use of textbooks is mainly caused by teachers' insufficient interpretation of the textbooks. In many universities, not as much importance is given to teaching as to research. This is especially true after the introduction of performance appraisal into the university evaluation system. Under greater pressure of academic research, teachers could not afford the same energy to teaching. Less qualification in professional levels among the teachers of the Integrated Course in Elementary Japanese makes things worse in the sense that they often regard textbooks as a teaching instrument. They make little reflections or evaluation of the textbooks they are using, and seldom conduct research or exploration of the ideas, layout, content, and the underlying relationship between different parts of the textbooks, not to mention the survey on students' opinion about the textbooks selected for them.

\section{Teachers' Unwillingness to Upgrade Textbooks in Teaching}

With many years of teaching and experience gained, quite a number of teachers have formed fixed concepts of teaching and follow their habitual way of teaching without considering the changes of time or 
students. Every textbook is compiled with certain concept of teaching, and teachers are often used to the concept of the textbook they are using. With the habits formed through many years' teaching, some books are regarded as classics. Therefore, they are unwilling to risk the trouble of making another round of preparations for class with the new books. In this sense, teachers who would rather keep the books they have been using for years hold back the change into the latest textbooks.

\section{Proposals for Textbook Selection}

Just as the saying goes, "Good tools are prerequisite to the successful execution of a good job", favorable teaching quality is based on favorable textbooks. The previous parts analyze the problems and factors in the selection of teaching materials. Based upon personal teaching experience, the author attempted to put forward some suggestions of selecting textbooks for the Integrated Course in Elementary Japanese.

\section{Setting the Direction of Textbook Selection Through the Interpretation of the Program}

When making the program of the Japanese majors, the Japanese departments of Chinese universities must not only follow the regulations of the National Syllabus for Japanese Education, but also consider the expectations on Japanese graduates from the employers and especially the status quo of teachers and students so that the program will be more properly oriented and the objective of talent training will be more clearly specified. Meanwhile, the courses must be offered in accordance with the objectives of talent training. The author would like to take the Japanese Department of Southwest University as an example. As the Japanese major is defined as one which trains talents for specific applied fields, more credits and teaching hours are given to skilled-oriented courses, such as speaking, interpreting, written translation, reading, and class discussion. In drafting and revising the program, all the teachers have been asked to participate in the discussion. After the program is made, an interpretation is made to all the teachers so as to help them understand the purposes, role, and interrelation of all the courses. A special emphasis is given to the Integrated Course in Elementary Japanese. In this way, textbooks are selected systematically for a common objective defined in the program rather than separately.

\section{Finding the Solution to the Puzzles of Textbook Selection Through Comparison}

Shu and Zhang (2003) emphasized that:

As textbooks serve the teachers and students, they should not be regarded as the instrument of determining the contents and methods of teaching. When selecting textbooks, teachers should judge whether the book selected serves the requirements of the actual teaching, including three aspects, namely, the requirement of students' learning, teachers' teaching, and curriculum, among which students' learning is of utmost importance. (p. 62)

Therefore, textbooks are not to be decided just by the dean or the director of the department. First, all teachers are to be involved to make a survey of all the major textbooks in the market and a detailed discussion of each type. Jin and Wang (2012) suggested that "The content, layout, structure, design, and teaching applications will exert significant influence on the quality of teaching and education" (p. 13). In terms of content, the accuracy or difficulty of the language training materials should be considered to check whether they are interesting, applicable, standard, and academically correct and whether the content and activities are properly arranged. In terms of the format, attention must be paid to the amount and proportion of words and texts, the diversification of exercises, as well as cover design, fonts, size of words, spaces, and quality of paper. In terms of teaching ideals, it is necessary to consider whether the emphasis is given to the training of basic 
skills, basic knowledge, cross-cultural communicative skills, and self-learning ability. Only after all the above mentioned considerations are made would a final decision be made of what textbooks to be selected. Through a holistic consideration of all factors, finally, the Comprehensive Japanese published by Peking University Press was selected as the course book for Integrated Course in Elementary Japanese.

\section{Test of Appropriateness Through Class Preparation in Groups}

To check whether the selected textbooks are appropriate or not, teachers are organized into groups according to the courses they are teaching. The textbook Comprehensive Japanese is selected at Southwest University for the three courses of Integrated Japanese, Japanese Listening, and Conversational Japanese, which makes it possible to make full use of all the exercises suggested in the textbooks. A large number of speaking activities in the textbooks are especially useful in the speaking class. Preparing lessons in a group and sharing one textbook by three courses help to build connection between different courses. At the same time, additional materials are used so as to "teach with the textbook" rather than to "teach the textbook". The textbook in this context is just a "blueprint" rather than "a book of texts", or even "a book of sacred texts" (Li, 2008). This will also help to train students' self-learning ability. In addition, group preparation of class and mutual observation of classroom teaching encourage teachers to change their own ideas of teaching and more importantly, help them find the appropriateness of the textbook from different perspectives and standpoints.

\section{Insurance of Textbook Quality Through the Evaluation of Both Teachers and Students}

All reform will be held back unless innovation is adopted in ideals of evaluation and judgment. Professor Li Guanyi said, "A good textbook may turn out to be awkward if evaluated by an mediocre reviewer, while a moderate textbook may turn out to be a good one if evaluated by a wise reviewer" (Li, 2002, p. 61). It could be safely said that the role of teachers and students is indispensable in the evaluation of any textbook. After two years of use among the Japanese majors, an investigation was made about the textbook Comprehensive Japanese. A survey was conducted on the teachers and students with interviews and questionnaires. Both the teachers and students reflect that this textbook is appropriate for Japanese majors at Southwest university, which implies the quality of education in training.

\section{Conclusion}

To sum up, textbooks are the crucial part of national syllabus, the major guidance for teachers' teaching, and the content of students' learning activities. Effective selection of textbooks plays an essential role in classroom teaching. This paper takes the Integrated Course in Elementary Japanese as a case study to probe into the ways of selecting textbooks for foreign language majors of Chinese universities. Based on the analysis of the problems and factors involved, the author put forward some proposals for textbook selection. It is believed that selection of textbooks is even more important than textbook editing, and a good use of the textbook is the prerequisite of textbook selection. Teachers should regard the textbook as a "blueprint" rather than "a book of texts", and give more emphasis on "teaching with the textbook" rather than on "teaching the textbook". Of course, it is expected that further research will be carried out on how to use and evaluate the textbook selected.

\section{References}

Gu, J. J., \& Lu, Y. H. (2009). A strategic account of the optimization and constraint of textbooks. Journal of Hebei Normal University, 8, 47-51. (In Chinese) 
Japanese Language Teaching Advisory Board. (2001). National syllabus for the elementary stage of Japanese majors. Dalian: Dalian University of Technology Press. (In Chinese)

Jin, Y. L. (2014). The operating mechanism and promotion of textbook selection. Curriculum, Teaching Material and Method, 8 , 12-18. (In Chinese)

Jin, Y. L., \& Wang, H. X. (2012). The gain and loss of the 10 years teaching material construction. Curriculum, Teaching Material and Method, 1, 12-16. (In Chinese)

Li, X. (2008). "Teaching textbooks" or "using textbook": A perspective of improving teaching materials function. Exploring Education Development, 10, 82-85. (In Chinese)

Li, Z. W. (2002). Mr. Li Guanyi on foreign language learning. Foreign Language World, 6, 2-4. (In Chinese)

Lu, X. D. (2010). Textbook selection and editing at the colleges and universities. China University Teaching, 10, 30-33. (In Chinese)

Shu, D. F., \& Zhang, Y. G. (2004). A questionnaire survey into the role of textbooks in the learning and teaching of a foreign language. Foreign Language World, 2(100), 56-64. (In Chinese)

Xiu, G. (2014, April 17-18). On building the Japanese specialty and cultivating students' intercultural communicative competence. Report presented at The Third National Forum for Deans/Directors of Japanese Departments, Hangzhou Normal University, Hangzhou, China. (In Chinese)

Yang, H. J., \& Peng, Y. Q. (2010). The ideal textbooks for intensive reading in the eyes of Japanese majors. Journal of the Chinese Society of Education, S1, 66-68. (In Chinese)

Yu, J. K. (2013, June 19). Who has the say over textbooks? A dialogue on the scientific selection of textbooks according to the curriculum standard. China Education Daily, p. 5. (In Chinese) 